УДК 621.787 .4

DOI: https://doi.org/10.36910/6775-2313-5352-2019-14-3

Бадір К.К.

Національний авіаційний університет

\title{
МОДЕЛЮВАННЯ ПРОЦЕСУ МАГНІТО-ТУРБУЛЕНТНОГО ОЧИЩЕННЯ ПІДШИПНИКІВ КОЧЕННЯ
}

Ресурс $i$ експлуатаційні характеристики трибосистем кочення та, нормальна працездатність машин і механізмів в иілому суттєво залежать від чистоти їх робочих поверхонь. $У$ результаті підвищення ефективності очищення трибовузлів машин $i$ змамувальних робочих рідин ресурс механізмів изих машин може бути збільшено в 2-3, а у випадках з прецизійними вузлами - до 10 разів. Таким чином, забезпечення $і$ контроль чистоти трибосистем кочення, дозволить покрашити їх експлуатаційні характеристики та збільшити ресурс, щуо на сьогодні $\epsilon$ актуальним науково-технічним завданням. Одним із способів підвищення ресурсу та покращення експлуатачійних характеристик підиипників кочення $\epsilon$ ефективне видалення забруднень з робочих поверхонь, що має особливе значення для спеціальних та прецизійних підшипників, які широко використовуються в різних галузях промисловості, та дає змогу запобігти передчасному їх зношуванню і скоротити витрати на обслуговування й ремонт. Літературний аналіз та результати досліджень показали, що віброакустичні параметри (віброшвидкість та віброприскорення), як основні параметри стану якості трибосистем кочення, безпосередньо залежать окрім точності виготовлення $i$ складання, також від чистоти робочих поверхонь та відсутності різного роду забруднень, зокрема металічних.

Ключові слова: моделювання, очищення, підшипник, забруднення, магнітне поле

Для вивчення процесів, що мають місце під час видалення механічних забруднень 3 поверхонь підшипників кочення, 3 метою розробки ефективних методів і засобів очищення була побудована фізико-математична модель. В якій розглянуто вплив складових сил, що здійснюють вплив під час видалення забруднень 3 трибосистем кочення змінним імпульсним магнітно-турбулентним методом.

При взаємодії електромагнітних полів 3 поверхнями деталей підшипника кочення відбувається взаємне переміщення рухомих елементів його конструкції, що перебуває в стадії очищення та формування гідравлічних потоків миючого середовища $[1-4,7]$.

Математична модель процесу видалення забруднень та залишків змащувальних матеріалів 3 поверхонь деталей підшипників кочення побудована 3 використанням наступних припущень:

1. Частинка забруднення має сферичну форму.

2. Розглядається зовнішнє кільце підшипника, поверхня якого є ідеальним циліндром.

3. Сила зчеплення частинки забруднення 3 поверхнею підшипника не залежить від напрямку зміщення забруднення і спрямована протилежно до зміщення.

4. Взаємодія частинки забруднення 3 підшипником та рідиною 3 достатньою точністю описується законами класичної механіки та гідравліки.

Розглянемо сили, що діють на забруднення сферичної форми, яке міститься на поверхні кільця підшипника (рис. 1 а, б). Кільце підшипника обертається в миючій рідині.

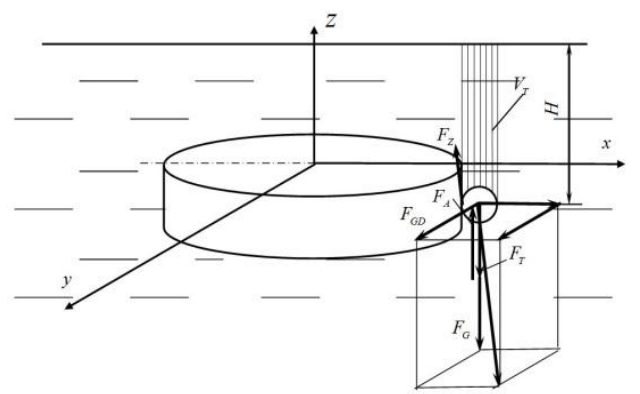

a)

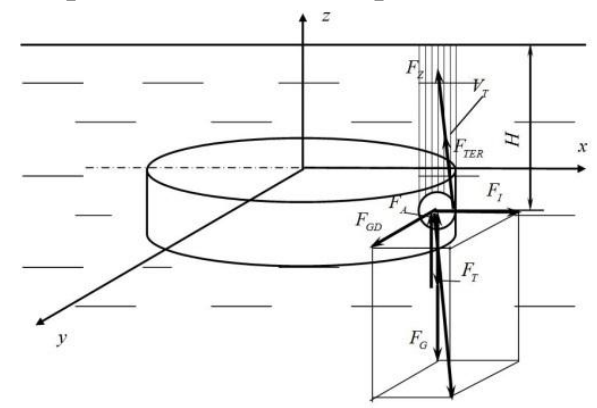

б)

Рис. 1. Сили, що діють на забруднення сферичної форми: а - на зовнішній поверхні кільця підшипника; б - на внутрішній поверхні кільця підшипника 
До них належать:

1. Сила тяжіння

$$
F_{T}=m g,
$$

де $m$ - маса частинки забруднення, кг; $g$ - прискорення вільного падіння $g=9,8 \mathrm{~m} / \mathrm{c}^{2}$.

2. Сила зчеплення частинки забруднення 3 матеріалом кільця підшипника $F_{Z}$. Враховуючи, що матеріал забруднення варіюється, сила зчеплення також може мати різну природу, що ускладнюе іï теоретичне визначення і переводить цю задачу в область експериментальних досліджень.

3. Сила Архімеда, що прагне виштовхнути частинку забруднення з середовища,в якому вона знаходиться (очищувальної рідини):

$$
F_{A}=\rho g V
$$

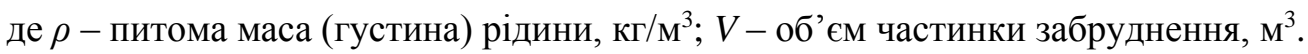

Згідно прийнятого нами припущення, що частинка має сферичну форму: $V=\frac{4}{3} \pi r^{3}$, $r$ - радіус частинки.

Тоді з врахуванням (3) вираз (2) для визначення сили Архімеда прийме вигляд:

$$
F_{A}=\frac{4}{3} \rho g \pi r^{3} .
$$

Слід зазначити, що сила Архімеда діє не лише на частинку рідини, але й на обойму підшипника. Суттєвим вплив сили Архімеда $є$ за умови, що питома маса матеріалу забруднення $\epsilon$ менша за питому масу рідини або одного порядку з нею. Якщо $\rho_{Z}>\rho$ ( $\rho_{Z}$ - питома маса забруднення кг $\left./ \mathrm{M}^{3}\right)$, то сила Архімеда не чинить суттєвого впливу на видалення забруднення і $1 i 1$ можна не враховувати.

5. Вертикальна складова сили тиску, що сприяє осадженню забруднення:

$$
F_{G}=\rho g V_{T},
$$

де $V_{T}$ - об’єм тіла тиску, що обмежене вільною поверхнею рідини, поверхнею забруднення та вертикальною циліндричною поверхнею, що проходить по контуру поверхні забруднення.

3 геометричних міркувань

$$
V_{T}=\pi r^{2} H-2 / 3 r^{3}=\pi r^{2}(H-2 / 3 r),
$$

де $H$ - глибина занурення центра мас частинки забруднення під вільну поверхню рідини, м.

Формула (5) з врахуванням (6) матиме вигляд:

$$
F_{G}=\rho g \pi r^{2}(H-2 / 3 r),
$$

Величина вертикальної складової сили тиску прямопропорційна глибині занурення цента мас частинки забруднення під вільну поверхню рідини. Горизонтальні складові сили тиску на частинку забруднення врівноважуються, тому їх не враховано. Видалення деяких забруднення відбувається ще до надання підшипнику певної частоти обертання, на етапі занурення його в рідину.

При цьому можливо два випадки:

а) частинка забруднення спливає на вільну поверхню рідини, якщо

$$
F_{A}>F_{T}+F_{G}+F_{Z} \text {. }
$$

Підставивши в формулу (8) вирази (1), (4), (7) отримаємо умову спливання забруднення на поверхню рідини за умови відсутності обертання підшипника:

$$
F_{Z}<\rho g \pi r^{2}(2 r-H)-m g,
$$

що можливе при умові $m<\rho g \pi r^{2}(2 r-H)$.

б) частинка забруднення опускається на дно миючої камери з рідиною

$$
F_{A}+F_{Z}<F_{T}+F_{G}
$$

Підставивши в формулу (10) вирази (1), (4), (7) отримано умову опускання забруднення на дно миючої камери з рідиною, за умови відсутності обертання підшипника:

$$
F_{Z}<\rho g \pi r^{2}(2 r-H)+m g
$$

Формула (11) є умовою гідростатичного осадження забруднення, аналіз якої свідчить, що можна підібрати таку глибину занурення $H$, за якої ця умова буде виконуватись, а отже 
забруднення будуть видалятися. Проте, через великі сили зчеплення реалізація цієї умови може вимагати занурення підшипника на більшу глибину.

2. Відцентрова сила інерції

$$
F_{I}=m \omega^{2} R
$$

де $\omega=\pi n / 30$ - кутова швидкість обертання кільця підшипника, рад/с; $n$ - частота обертання кільця підшипника, об/хв., $R$ - відстань від центу обертання до центра мас частинки забруднення.

Слід зазначити, що для забруднення, що знаходиться на зовнішній поверхні кільця підшипника, відцентрова сила сприяє видаленню забруднення, а для частинки, що міститься на внутрішній поверхні кільця підшипника (рис. 1 б), навпаки, ускладнює видалення забруднення, створюючи додаткову силу тертя між частинкою забруднення та кільцем підшипника:

$$
F_{\text {TER }}=k_{0} F_{I},
$$

де $k_{0}$ - коефіцієнт тертя спокою, що залежить від матеріалу забруднення та матеріалу кільця підшипника.

Тоді формула (13) з врахуванням (12) матиме вигляд:

$$
F_{T E R}=\frac{k_{0} \pi^{2} m n^{2} R}{900},
$$

Тому з підвищенням частоти обертання підшипника видалення забруднень з внутрішніх поверхонь кільця підшипника ускладнюється, що обмежує частоту обертання підшипника.

6. Сила опору руху частинки забруднення рідини, яка залежить від швидкості руху рідини і визначається:

- для ламінарного режиму за формулою Стокса:

$$
F_{G D}=6 \pi \mu r v
$$

де $\mu$ - коефіцієнт динамічної в'язкості рідини Па·с; $v$ - середня швидкість рідини. Для ламінарного режиму

$$
v=u_{\max } / 2
$$

де $u_{\max }$ - максимальна швидкість.

Внаслідок наявності в'язкості рідини ії шари, що контактують 3 поверхнею кільця підшипника мають швидкість відносно рухомої поверхні близьку до нуля і рухаються з такою ж швидкістю (рис. 2 а, б) [5, 6]. Тому максимальна швидкість визначається як:

$$
u_{\max }=\omega R_{1}=\frac{\pi n R_{1}}{30} .
$$

де $R_{1}$ - відстань від центру обертання до точки контакту поверхні підшипника з забрудненням.

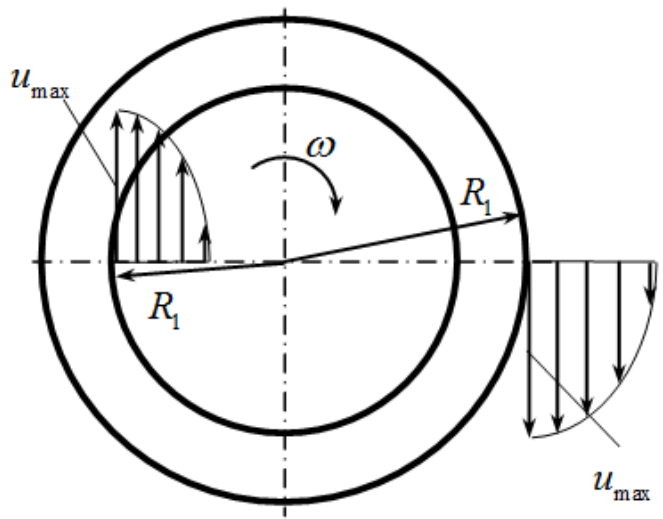

a)

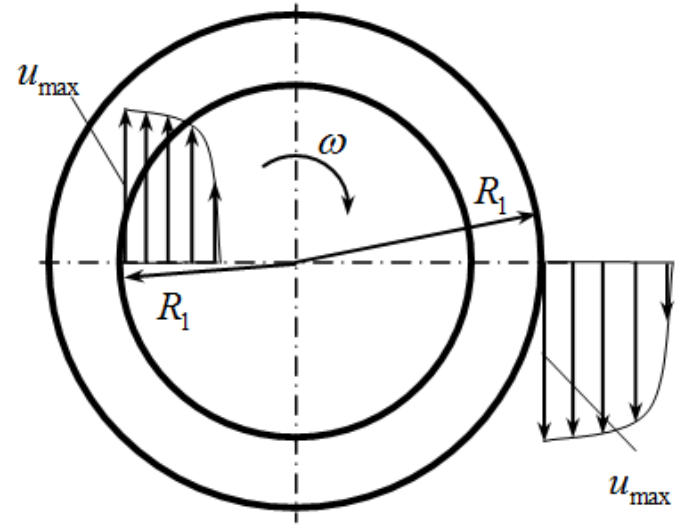

б)

Рис. 2. Розподіл швидкостей в контактному шарі з поверхнею кільця підшипника: a ламінарний рух; б - турбулентний рух

3 урахуванням (16) та (17) формула Стокса (15) матиме вигляд:

$$
F_{G D}=\frac{\pi^{2} \mu r n R_{1}}{10} .
$$

- для турбулентного режиму руху за законом Ньютона:

\section{(C) Бадір К.К.}




$$
F_{G D}=C_{x} \frac{\rho v^{2}}{2} S
$$

де $C_{X}$ - коефіцієнт лобового опору, що характеризує форму тіла; $v$ - середня швидкість рідини.

Для турбулентного режиму $v=\frac{u_{\max }}{1,15 \ldots 1,3}$. Тому приймемо, що:

$$
v=\frac{u_{\max }}{1,2}
$$

$S$ - площа проекції тіла на площину, що перпендикулярна до напрямку руху.

Для сферичної частинки забруднення:

$$
S=\pi r^{2} / 4
$$

3 врахуванням (17), (20), (21) формула (19) набуде вигляду:

$$
F_{G D}=C_{x} \frac{\pi^{2} \rho n^{2} R_{1}^{2} r^{2}}{10368} .
$$

Таким чином, для видалення забруднення під час обертання підшипника необхідно щоб виконувались наступні гідродинамічні умови:

А) для частинки, що міститься на зовнішній поверхні кільця підшипника:

$$
\sqrt{F_{G D}^{2}+\left(F_{T}+F_{G}-F_{A}\right)^{2}+F_{I}^{2}}>F_{Z} .
$$

Б) для частинки, що міститься на внутрішній поверхні кільця підшипника:

$$
\sqrt{F_{G D}^{2}+\left(F_{T}+F_{G}-F_{A}\right)^{2}+F_{I}^{2}}-F_{T E R}>F_{Z} .
$$

Характер переміщення електромагнітного поля забезпечують періодичне розмагнічування матеріалу підшипника, коли сумарний вектор протікання струмів в матеріалі дорівнює нулю і сили магнітної взаємодії забруднення з деталями підшипнику зникають. При цьому під дією інших складових сил взаємодії частки забруднення переходять у миючий розчин при виконанні гідродинамічних умов (23), (24). Далі, коли 3'являється зовнішне магнітне поле (МП) на забруднення буде діяти сила взаємодії магнітних зарядів, а так як напруженість зовнішнього МП більша за напруженість поля на поверхні деталей підшипників, це буде сприяти видаленню забруднення в потік в напрямку додаткового зовнішнього імпульсного магнітного поля (ДЗІМП).

Для визначення параметрів біжучого магнітного поля проведено ряд експериментів. Це пов'язано з урахуванням великої кількості факторів через особливості різних конструкцій підшипників кочення і матеріалів, з яких вони виготовлені, а також складу та стану забруднень, що призводить до слабкої кореляції математичних розрахунків.

На основі отриманих результатів експериментальних даних, індукція МП на поверхні герметичної камери складає 140 мТл, зовнішнє кільце підшипника має залишкову намагніченість близько 10 мТл, внутрішнє кільце - 9 мТл, індукція МП підшипника на відстані 15 мм від дна камери - 100 мТл.

Параметри МП, необхідні для ефективного видалення з робочих поверхонь трибосистем кочення мікро- та субмікрочасток забруднень це:

- амплітуда МП - для забезпечення ефективного видалення забруднень, повинна бути не меншою за половину висоти обойми (для середньої серії підшипників становить $13 \ldots 15$ мм);

- номінальна частота зміни полюсів імпульсного МП;

- ефективний час очищення в межах визначених оптимальних амплітуди магнітної індукції і частоти змінного імпульсного МП.

В якості миючої рідини використовувалось авіаційне паливо (РТ, ТС-1).

Магнітне поле ДЗІМП складається 3 двохполюсних елементів, що виконані 3 магнітотвердих матеріалів, і які розташовані почергово -S-N-S-...S-N- на диску виконаному 3 заліза Армко або сталі 10 і служить магнітопроводом. Максимальна відстань дії ДЗІМП на підшипникову сталь ШХ15 виникає при повному ії приляганні до джерела МП. Магнітна індукція одиничного джерела постійного магнітного поля (ДПМП) складає 450 мТл. Зі 
збільшенням відстані до 50 мм ця величина зменшувалась до нуля. Після витримування зразка зі сталі ШХ15 на поверхні постійного магніту протягом 20 хв. ступінь намагніченості оцінювався тесламетром ЕМ 4305/1 і досягав 20 мТл. При очищенні трибосистеми кочення іiі поверхні знаходяться на відстані, яка складається з: відстані від поверхні джерела МП до дна камери; товщини матеріалу камери; відстані від нижньої поверхні підшипника до дна камери. Індуктивність МП в цьому випадку за рахунок екранування композиційним матеріалом камери зменшувалась до 140 мТл, а враховуючи відстані від підшипника до дна камери - 100 мТл. Це можливо досягти (враховуючи екранування елементами конструкції миючої ванни) використанням в якості ДПМП елементів, що виконані 3 магнітотвердих матеріалів дисперсійного твердіння системи неодим-залізо-бор, або самарій-кобальт, або застосуванням потужних електромагнітів.

При постійному МП намагніченість поверхонь підшипників мала пелюстковий характер (рис. 3., рис. 4). Найбільший рівень (рис. 3) намагніченості спостерігався на зовнішньому кільці підшипника і сягав 10 мТл. Внутрішне кільце і тракт кочення намагнічуються до 9 мТл.

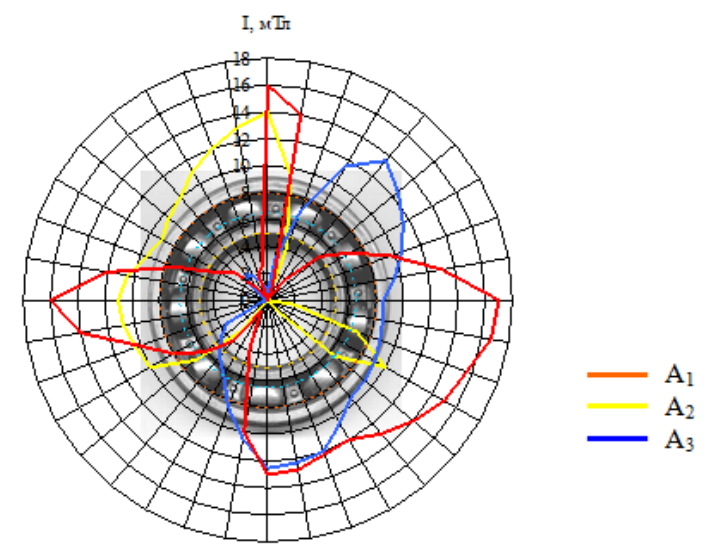

Рис. 3. Розподіл магнітної індукції $I$ поверхонь деталей підшипника відносно радіусів зовнішнього $\left(\mathrm{A}_{1}\right)$ і внутрішнього кілець $\left(\mathrm{A}_{2},\right)$ та сепаратора 3 тілами кочення $\left(\mathrm{A}_{3}\right)$ після 10 хвилин намагнічування джерелом постійного МП

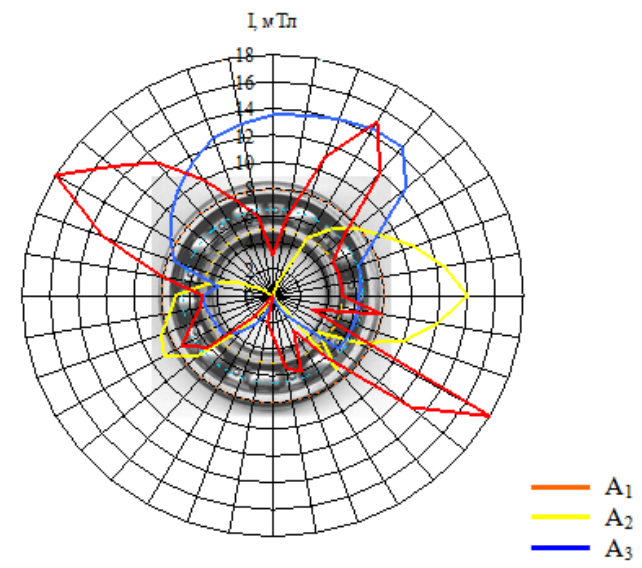

Рис. 4. Розподіл магнітної індукції $I$ поверхонь деталей підшипника відносно радіусів зовнішнього $\left(\mathrm{A}_{1}\right)$ і внутрішнього кілець $\left(\mathrm{A}_{2},\right)$ та сепаратора 3 тілами кочення $\left(\mathrm{A}_{3}\right)$ після 20 хвилин намагнічування джерелом постійного МП

Максимальна робоча частота змінного імпульсного МП повинна бути не менше 1000 Гц, оскільки експериментально встановлено, що на меншій частоті організація безконтактного обертання зовнішньої обойми об'єкта очищення ускладнена, а перевищення частоти в 5000 Гц викликає активний неконтрольований відтік миючої рідини від об'єкта очищення, що призводило до падіння ефективності видалення забруднень. Тому дослідження ступеня намагніченості проводились на цій та нижчих частотах. Згідно з результатами вимірювань (рис. 5) при взаємодії 3 полем визначеного значення протягом 5 хв. намагніченість деталей підшипників зменшувалась до 4...6 мТл.

Таким чином, згідно з результатами досліджень, при дії змінного імпульсного МП на об'єкт очищення, у випадку забезпечення оптимальних величини поля, частоти та часу 
очищення ступінь намагніченості не перевищує $10 \%$ від максимальної амплітуди напруженості джерела МП в робочій зоні. Зменшення магнітної індукції джерела МП, діючого на підшипник кочення призводить до зменшення рівня намагніченості його деталей.

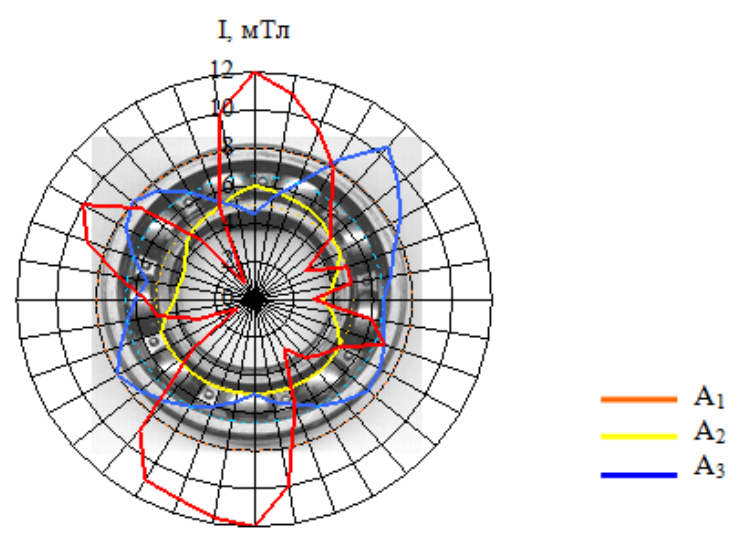

Рис. 5. Розподіл магнітної індукції $I$ поверхонь деталей підшипника відносно радіусів зовнішнього $\left(\mathrm{A}_{1}\right)$ і внутрішнього кілець $\left(\mathrm{A}_{2},\right)$ і сепаратора з тілами кочення $\left(\mathrm{A}_{3}\right)$ після очищення протягом 3 хвилин при частоті імпульсного МП 4800 Гц

Таким чином, при односторонньому позиціонуванні для МП з зоною дії поля в 20 мм очищення буде ефективним для підшипників з висотою кілець до 15 мм. При двосторонньому позиціонуванні (при перестановці підшипника в змінному імпульсному МП з однієї сторони на іншу), очищення буде ефективним для підшипників 3 висотою кілець до 40 мм. Збільшення висоти кілець потребує створення ДМП з більшою індукцією та зоною дії поля і більшою напруженістю, або з більш складною конструкцією магнітопроводу.

\section{Інформаційні джерела}

1. Белянин П. Н., Данилов В. М. Промышленная чистота машин. - М.: Машиностроение, 1982. - 224 с. Коваленко В.П. Загрязнение и очистка нефтяных масел. М.: Химия, 1978. 302 с.

2. Глезер А. М. Аморфные и нанокристаллические структуры: сходства, взаимные переходы. / А. М. Глазер // Рос. Хим. Ж., 2002. - Т.-№5.-С. 57-63.

3. Захаров В.А., Боровкова М.А., Комаров В.А., Мужицкий В.Ф. Влияние внешних напряжений на коэрцитивную силу углеродистых сталей. - Дефектоскопия, 1992, № 1, с. 41-46.

4. Крагельский И.В., Добычин М.Н., Комбалов В.С. Основы расчетов на трение и износ. М., «Машиностроение», 1977г. - 526 с.

5. Расчет ресурса подшипников качения при переменных режимах нагружения / О.Леликов. - М.: Машиностроение, 2008. - 211 с. Справочник. Инженерный журнал: приложение к журналу.

6. Явленский А. К. Влияние макрогеометрии беговых дорожек колец подшипников на характер контактирования шариков с кольцами. - Труды ЛИАП, 1971, вып.. 73, С. 138-145.

7. Ткачук А.А. Підвищення зносостійкості фрикційних поверхонь обертання методами поверхневого пластичного деформування / А.А. Ткачук, В.Ю. Заблоцький, В.О. Дзюра // Перспективні технології та прилади. Збірник наукових праць. - Луцьк: ЛНТУ, 2014. - №5 (2). C. $158-163$.

\section{Бадир К.К.}

Национальный авиационный университет

МОДЕЛИРОВАНИЕ ПРОЦЕССА МАГНИТО-ТУРБУЛЕНТНОЙ ОЧИСТКИ ПОДШИПНИКОВ КАЧЕНИЯ

Ресурс и эксплуатационные характеристики трибосистем качения и, нормальная работоспособность машин и механизмов в иелом существенно зависят от чистоты их рабочих поверхностей. В результате повышения эффективности очистки вузлов машин и смазочных рабочих жидкостей ресурс механизмов этих машин может быть увеличено в 2-3, а в случаях с прецизионныли узлами - до 10 раз. Таким образом, обеспечение и контроль чистоты трибосистем качения, позволит улучшить их эксплуатаџионные характеристики и увеличить ресурс на сегодня является актуальным научно-техническим заданием. Одним из 
способов повышения ресурса и улучшения эксплуатационных характеристик подшипников качения является эффективное удаление загрязнений с рабочих поверхностей, имеет особое значение для специальных и пречизионных подшипников, которые широко используются в различных отраслях промышленности, и позволяет предотвратить преждевременное их износ и затраты на обслуживание и ремонт. Литературный анализ и результаты исследований показали, что виброакустические параметры (виброскорость и виброускорения), как основные параметры состояния качества трибосистем качения, напрямую зависят кроме точности изготовления и сборки, а также от чистоты рабочих поверхностей и отсутствии разного рода загрязнений, в том числе металлических.

Ключевые слова: моделирование, очистка, подшипник, загрязнения, магнитное поле

\section{K. Badir}

National Aviation University

\section{MODELING THE PROCESS OF MAGNETIC-TURBULENT CLEANING OF} ROLLING BEARINGS

The resource and operational characteristics of the rolling tribosystems and the normal operation of machines and mechanisms as a whole substantially depend on the cleanliness of their working surfaces. As a result of increasing the cleaning efficiency by tribo-tilting machines and lubricating fluids, the life of the mechanisms of these machines can be increased by 2-3, and in cases with precision assemblies - up to 10 times. Thus, the provision and control of the purity of the rolling tribosystems will allow to improve their performance and increase the resource today is a relevant scientific and technical task. One of the ways to increase the service life and improve the performance of rolling bearings is the effective removal of contamination from working surfaces, is of particular importance for special and precision bearings, which are widely used in various industries, and helps prevent their premature wear and maintenance and repair costs. Literary analysis and research results showed that vibroacoustic parameters (vibration velocity and vibration accelerations), as the main parameters of the quality of the tribosystem rolling, directly depend on the accuracy of manufacturing and assembly, as well as on the cleanliness of working surfaces and the absence of various kinds of pollution, including metallic ones.

Keywords: modeling, cleaning, bearing, pollution, magnetic field 